\title{
AUTHORSHIP MALPRACTICES IN DEVELOPING COUNTRIES
}

Received: Nov 1, 2019

Accepted: Nov 5, 2019

Horacio Rivera ${ }^{\mathbf{1 , 2}}$ https://orcid.org/0000-0001-6940-0668

1 Division of Genetics, Western Biomedical Research Center, Mexican Institute of Social Welfare, Guadalajara, Mexico

2Department of Molecular Biology and Genomics, University Center of Health Sciences, University of Guadalajara, Guadalajara, Mexico

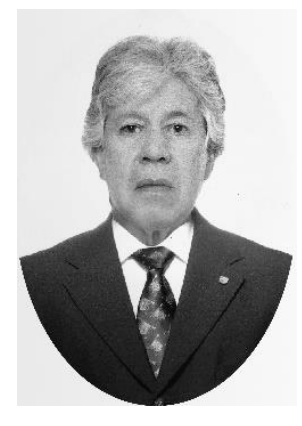

\section{*Corresponding author:}

Horacio Rivera, División de Genética, CIBO, Instituto Mexicano del Seguro Social, Sierra Mojada 800, C.P. 44340, Guadalajara, Mexico;

E-mail: horacio.rivera@academicos.udg.mx

\begin{abstract}
Although the variety of research malpractices in low- and middle-income countries (LMIC) is similar to those documented in developed nations, authorship misuse and related issues appear to be more prevalent in the former. This article focuses on some authorship-related topics in LMIC, namely authorship disputes, excessive co-authorship and monetary incentives, authorship issues in student-mentor relationships, and authorship patterns in North-South collaborations. Universities and official bodies in LMIC must supervise the integrity of the whole research process, provide instructions on responsible research and authorship, set up the required postgraduate training programs, foster good role models in authorship, and designate an ombudsperson to advice and respond to complaints of researchers, especially students and junior faculty. Lastly, a recent framework that combines descriptive and normative elements and then uses proper metaphors to achieve an ethical definition of authorship useful in international settings is highlighted.
\end{abstract}

Keywords: Authorship, Low- and middle income countries, Monetary incentives, Student-mentor relationships, North-South collaborations

How to cite: H. Rivera. Authorship malpractices in developing countries. Cent Asian J Med Hypotheses Ethics 2020;1(1):69-74. https://doi.org/10.47316/caimhe.2020.1.1.11

\section{INTRODUCTION}

In contrast with the small contribution of low- and middle-income countries (LMIC) to the scientific endeavor, research malpractices therein are similar to those in developed nations but feature a greater prevalence of authorship misuse [1-3]. This mistreat may reflect the unawareness of the International Committee of Medical Journal Editors (ICMJE) authorship criteria and related guidelines [4]. In this regard, the perceived reluctance of authors from the 


\section{Central Asian Journal of Medical Hypotheses and Ethics| \\ 2020; Vol 1}

Asia-Pacific region to adhere to Western and international guidelines has been ascribed to cultural barriers at play $[5,6]$. Anyway, it seems that the lack of teaching and training in scientific integrity and good publication practices $[5,6]$ along with the widespread corruption in many LMIC [7] further reinforces authorship abuses therein. Here, I'll focus on some authorship-related topics in LMIC.

\section{AUTHORSHIP DISPUTES}

Aside from anecdotal experiences [8], the few studies on the prevalence of authorship disagreements or disputes in LMIC $[9,10]$ indicate that such conflicts are frequent. In their study based on a questionnaire responded by $\sim 200$ Cochrane corresponding authors from LMIC and in-depth interviews with 15 of them, Rohwer et al. [9] found that authorship issues, including quarrels about the order of authors, were a common concern.

Among 967 South African researchers from all fields surveyed by Breet et al. [10], many respondents experienced disagreement on who qualifies for coauthorship (59\%) or authorship order (48\%). As a measure "to counter questionable authorship practices and disagreements about authorship and the order of authors", these researchers emphasized the need for institutions to develop strategies for resolving disputes and for postgraduate programs to train students on authorship guidelines and their application. A recent review focused on authorship disputes around the world [11] identified a dozen of underlying drivers including the pervasive "publish or perish" mindset [12] as the key one.

To prevent these disagreements, Annunziata and Giordano [13] proposed that every research group should commit to full transparency with respect to ongoing projects and their authors; that is, to make research manuscripts fully available for all group members. When prevention fails, conflicts can remain unresolved and even become bitter if managed only by the concerned researchers; hence, alternative approaches have been advanced. For instance, a guide on how to handle such disputes [14] and several approaches based on arbitration or mediation by non-peer individuals, or led by research ethics consultants or ideally by a panel of peers working in close fields and qualified on publication ethics [15-17], have been advanced.

Excessive co-authorship and monetary incentives The steady increasing in the number of authors per article has become more visible since the decade of 1970. Although genuine collaborative efforts required by the complexity of science are a relevant factor, there are other not-so-legitimate forces that also operate, noticeably the "publish or perish" pressure linked to promotion or tenure [12] and monetary incentives granted to publications in journals with a certain impact factor [18]. These incentives mostly operate in some Asian (e.g., China, India, Pakistan, South Korea), African (e.g., South Africa) and Latin American (e.g. Mexico, Uruguay) countries but they are going global [19]; so, it is instructive to compare the schemas operating in two emerging nations with a reduced scientific output, namely Mexico and South Africa.

In 1984, the conjoint efforts of Mexican scientists and government led to the establishment of the Sistema Nacional de Investigadores (SNI, National Researchers System) which assigns an untaxed monetary reward to those researchers favorably evaluated by a peer panel that prioritizes articles in accredited journals (currently, there are 5 categories: candidate, level I, II or III, and emeritus). It must be noticed that the monetary stimulus is an enticement for personal use and represents a significant fraction of the salary [20]. Thus, to be a SNI member is out of question and has become a very coveted goal not only for individuals but also for universities and research centers. Actually, both researchers and institutions eagerly boast the SNI membership as an almost undisputable mark of quality $[20,21]$. Certainly, the $S N I$ has raised controversies and severe criticisms such as doubtful or biased evaluations [21-23], poorly qualified reviewers [24], and postponing the retirement of aged professors who do not wish to loss the extra income $[20,21]$.

In South Africa, a substantial part of the state subsidy earned by public universities reflects the implementation some 20 years ago of a national policy based on the number and quality of peerreviewed publications - namely articles in accredited journals, conference proceedings, and 


\section{Central Asian Journal of Medical Hypotheses and Ethics|}

2020; Vol 1

books or chapters - by researchers affiliated to those universities $[10,25]$. The amount paid per publication to each university is mostly used to maintain and develop the research infrastructure. Some universities pay an amount into the authors' accounts either to reinforce their research projects or as additional income, while other institutions assign funds on a competitive basis to support researchers' activities. Aside from a greater number of publications seen as a "success" and ascribed to the financial incentive, it has been remarked that such a schema favors listing co-authors who did not satisfy authorship criteria and related malpractices $[10,25,26]$.

Altogether, pay-per-publication schemas may favor misconduct [18]. For instance, a recent proposal of the Indian government aimed to reward graduate students who publish in reputed journals has been seen as a treat to the quality of research [27].

Authorship issues in student-mentor relationships As for the authorship of articles derived directly from the student's thesis or dissertation, it is commonly agreed that the student should be the first author whereas the mentor may appear as the corresponding author or even be omitted as a coauthor. Yet, the inequality inherent to graduate student-mentor relationships is sometimes fertile ground for the former being abused by the powerful professor $[13,28]$. Although such abuses occur everywhere, they seem more frequent or tolerated in LMIC. For instance, the aforementioned survey by Rohwer et al. [9] confirms that students and junior researchers working in LMIC are obliged to add their bosses or supervisors as co-authors or sometimes as first authors; a worst scenario features the powerful professor publishing student's research without the latter being included as a coauthor or aware of the professor's decision [25]. Hence, it has been proposed that a clear studentmentor agreement on authorship must be entered at the start of the relationship [26]. In this regard, a Colombian researcher fully knowledgeable of the practices in his country alerts on abusive mentorship and authorship [29].

Authorship patterns in North-South collaborations The 1990 report of the Commission on Health Research for Development and similar initiatives have fueled a growing North-South partnership in global health research and education between institutions of high-income countries (HIC) and LMIC $[28,30,31]$. Such collaborative efforts have significantly increased the number of published studies by LMIC authors, especially from Africa, but have increased even more the number and proportion of HIC lead authors. For instance, a review of 2,292 papers on maternal health interventional research carried out in LMIC and published from 2000 to 2012, disclosed marked deficiencies in lead authorship by local researchers in journals with an Impact Factor $>2.0$ and for systematic reviews and modeling studies [32].

In their study focused on authorship parity versus parasitism in pediatric research conducted in LMIC and published from 2006 to 2015 in 1,243 articles in 4 prestigious journals, Rees et al. [30] documented that while parasitism (no listed authors from LMIC in which studies were conducted) was indeed rare, there was a persistent disparity insofar as HIC authors often occupy the first and last author positions in articles conducted in low-income nations. A subsequent mixed-methods online survey [33] completed by 279 corresponding and non-corresponding authors from LMIC $(n=159)$ and HIC $(n=120)$ of the same 1,243 pediatric articles revealed that $\sim 65 \%$ of respondents $(n=181)$ from either LMIC $(n=98)$ or HIC $(n=83)$ blamed collaborators for inappropriately assigning authorship positions. Moreover, $~ 35 \%$ of LMIC and $\mathrm{HIC}$ researchers reported having been excluded from authorship despite making significant contributions. Finally, a seemingly large though not determined fraction of respondents questioned the validity of the ICMJE authorship guidelines for collaborative research conducted in LMIC.

\section{RECOMMENDATIONS AND CONCLUDING REMARKS}

Universities and official bodies in LMIC must promote and supervise the integrity of the whole research process from the wellbeing of study subjects to good publishing practices. In particular, teaching of responsible conduct of research and authorship guidelines as well as training for the proper application of the latter need to be included in postgraduate programs. Furthermore, all research institutions should designate an ombudsperson or committee to advice and receive 


\section{Central Asian Journal of Medical Hypotheses and Ethics| \\ 2020; Vol 1}

complaints from researchers, especially students and junior members [13]. In this regard, it has been remarked that young colleagues are aware of good practices but are discouraged from following them by the mentors and senior researchers as well as by the lack of good role models [9].

As a constructive recommendation for researchers from Central Asia but also applicable to scientists from other LMIC, I reiterate the plea made by several Asian-Pacific organizations on the need for academic institutions to raise ethical awareness and provide researchers with authorship guidance adapted to specific cultural settings and aimed to improve publication practices $[5,6]$. These institutions should play a proactive role in educating and strengthening the ethical culture of authors and reviewers via workshops, mentoring and rolemodeling rather than only relying on punitive actions such as rejection and retraction of papers $[5,28,34]$. Lastly, I highlight a recent effort [35] to harmonize the difficulties inherent to good authorship practices with the steady increase in international coauthorships in the natural sciences. These authors proposed a framework aimed at first to enrich the current descriptive definition of authorship with normative elements and then to use proper metaphors to improve the comprehension of such an ethical definition of authorship (instead of a mere good authorship) in international settings; i.e., a definition that explains not only "who is an author, but also readily clarifies who is an ethical author".

\section{FUNDING}

None

\section{AUTHOR CONTRIBUTION}

The author substantially contributed to the writing and revising the manuscript. He takes full responsibility for all aspects of the work.

\section{CONFLICTS OF INTEREST}

None

\section{DISCLAIMER}

No part of the manuscript has been submitted simultaneously or published elsewhere.

\section{REFERENCES}

1. Ana J, Koehlmoos T, Smith R, Yan LL. Research misconduct in low- and middle-income countries. PLoS Med 2013;10(3):e1001315.

2. Alshogran OY, Al-Delaimy WK. Understanding of International Committee of Medical Journal Editors authorship criteria among faculty members of pharmacy and other health sciences in Jordan. J Empir Res Hum Res Ethics 2018;13(3):276-284.

3. Shah A, Rajasekaran S, Bhat A, Solomon JM. Frequency and factors associated with honorary authorship in Indian biomedical journals: analysis of papers published from 2012 to 2013. J Empir Res Hum Res Ethics 2018;13(2):187-195.

4. Looi L-M, Wong LX, Koh CC. Scientific misconduct encountered by APAME journals: an online survey. Malays J Pathol 2015;37(3):213-218.

5. Olesen A, Amid L, Mahadi Z. Unethical authorship practices: A qualitative study in Malaysian higher education institutions. Dev World Bioeth 2018;18(3):271-278.

6. Hesp BR, Arai K, Chu MYS, Chuah S, Curameng JMB, Kamat S, et al. A guide to applying the Good Publication Practice 3 guidelines in the Asia-Pacific region. Res Integr Peer Rev 2019;4:21.

7. Rivera H. Inappropriate authorship and kinship in research evaluation. J Korean Med Sci 2018;33(13):e105.

8. Unintended consequences: how authorship guidelines destroyed a relationship. Available from: https://retractionwatch.com/2017/07/05/unintended-consequences-guidelines-destroyed-relationship/ [Accessed June 19, 2020].

9. Rohwer A, Young T, Wager E, Garner P. Authorship, plagiarism and conflict of interest: views and practices from low/middle-income country health researchers. BMJ Open 2017;7(11):e018467. 


\section{Central Asian Journal of Medical Hypotheses and Ethics| \\ 2020; Vol 1}

10. Breet E, Botha J, Horn L, Swartz L. Academic and scientific authorship practices: a survey among South African researchers. J Empir Res Hum Res Ethics 2018;13(4):412-420.

11. Beshyah SA, Ibrahim WH, Aburawi EH, Elkhammas EA. The rules and realities of authorship in biomedical journals: a cautionary tale for aspiring researchers. Ibnosina J Med Biomed Sci 2018;10(5):149-157.

12. Gasparyan AY, Ayvazyan L, Kitas GD. Authorship problems in scholarly journals: considerations for authors, peer reviewers and editors. Rheumatol Int 2013;33(2):277-284.

13. Annunziata $S$, Giordano A. Authorship problems in scientific literature and in nuclear medicine: the point of view of the young researcher. Eur J Nucl Med Mol Imaging 2014;41(6):1251-1254.

14. Albert T, Wager E. The COPE Report 2003. How to handle authorship disputes: a guide for new researchers. Available from: http://publicationethics. org/files/2003pdf12.pdf [Accessed June 19, 2020].

15. Faulkes Z. Resolving authorship disputes by mediation and arbitration. Res Integr Peer Rev 2018;3:12.

16. Faulkes Z. Pluralism in authorship dispute resolution: reply to Master and Tenenbaum. Res Integr Peer Rev 2019;4:10.

17. Master Z, Tenembaum E. The advantages of peer review over arbitration for resolving authorship disputes. Res Integr Peer Rev 2019;4:10.

18. Rivera H. Fake peer review and inappropriate authorship are real evils. J Korean Med Sci 2018;34(2):e6.

19. Abritis A, McCook A. Cash incentives for papers go global. Science 2017;357(6351):541.

20. Vera-Martínez H. Los cuatro jinetes de la evaluación: productivismo, reduccionismo, cuantofrenia y simulación. Rev Educ Sup 2018; 47(187): 25-48.

21. Bensusán G, Valenti G (Coord). La Evaluación Académica en México. Instituciones y Sistema Nacional de Investigadores, aciertos y controversias. Mexico DF, Flacso and UAM eds. 2018

22. Ricker M, Hernández HM, Daly DC. Measuring scientists' performance: A view from organismal biologists. Interciencia 2009;34(11):830-835.

23. Soberón MJ. Editorial Commentary. Interciencia 2010;35(3):159.

24. Frixione E, Ruiz-Zamarripa L, Hernández G. Assessing individual intellectual output in scientific research: Mexico's national system for evaluating scholars performance in the humanities and the behavioral sciences. PLoS One 2016;11(5):e0155732.

25. Louw DA, Fouché JB. Authorship credit in supervisor-student collaboration: assessing the dilemma in psychology. S Afr J Psychol 1999;29(3):145-148.

26. Joubert G. Authorship: practices and experiences in the faculty of health sciences of the University of the Free State. S Afr Fam Pract 2005;47(4):57-60.

27. Vaidyanathan G. Payment-for-papers plan rattles scientists. Nature 2019;566(7744):307.

28. Bukusi EA, Manabe YC, Zunt JR. Mentorship and ethics in global health: fostering scientific integrity and responsible conduct of research. Am J Trop Med Hyg 2019; 100(Suppl 1):42-47.

29. Ávila-Guerra M. Bullying in authorship: abusive mentorship and undeserved credit. Medwave 2014;14(4):e5950.

30. Rees CA, Lukolyo H, Keating EM, Daerden KA, Luboga SA, Schutze GE, et al. Authorship in paediatric research conducted in low- and middle-income countries: parity or parasitism? Trop Med Int Health 2017;22(11):1362-1370.

31. Schneider $\mathrm{H}$, Maleka N. Patterns of authorship on community health workers in low-and middle-income countries: an analysis of publications (2012-2016). BMJ Glob Health 2018;3:e000797.

32. Chersich MF, Blaauw D, Dumbaugh M, Pen-Kekana L, Dhana A, Thwala S, et al. Local and foreign authorship of maternal health interventional research in low- and middle-income countries: systematic mapping of publications 2000-2012. Global Health 2016;12(1):35.

33. Rees CA, Keating EM, Dearden KA, Haq H, Robison JA, Kazembe PN, et al. Importance of authorship and inappropriate authorship assignment in paediatric research in low- and middle-income countries. Trop Med Int Health 2019;24(10):1229-1242. 


\section{Central Asian Journal of Medical Hypotheses and Ethics| \\ 2020; Vol 1}

34. Hadji M, Asghari F, Yunesian M, Kabiri P, Fotouhi A. Assessing the prevalence of publication misconduct among Iranian authors using a double list experiment. Iran J Public Health 2016; 45(7):897904.

35. Hosseini M, Consoli L, Zwart HAE, van den Hoven MA. Suggestions to improve the comprehensibility of current definitions of scientific authorship for international authors. Sci Eng Ethics 2020; 26(2):597617.

\section{Түйіндеме}

Дамушы елдердегі авторлық құқықтарды бұзулар

Табысы төмен және орташа елдерде (TTOE) авторлық құқықты теріс пайдалану және онымен байланысты проблемалар дамыған елдерде тіркелген құқық бұзушылықтармен ұқсас болғанына қарамастан, бірінші топ елдерінде жиі кездеседі. Бұл мақалада авторлыққа қатысты кейбір тақырыптар, атап айтқанда авторлық туралы дау, шамадан тыс бірлескен авторлық және ақшалай ынталандыру, студент пен тәлімгер арасындағы авторлық мәселелер, Солтүстік-Оңтүстік ынтымақтастығындағы авторлық модельдер қарастырылады. LMIC-дегі университеттер мен билік органдары бүкіл зерттеу процесінің тұтастығын қадағалап, жауапты ғылыми зерттеулер мен авторлық нұсқаулықтар беруі керек, постдипломдық білім беруге қажетті бағдарламаларды құруы керек, авторлық шеберліктің жақсы модельдерін жасауы керек, сонымен қатар зерттеушілердің, әсіресе студенттер мен жас оқытушылардың шағымдарына жауап қату және кеңес беру үшін омбудсмен тағайындауы керек. . Соңында, сипаттамалық және нормативтік элементтерді біріктіретін құрылым пайда болады, сонымен қатар халықаралық контекстте авторлықтың тиімді этикалық анықтамасына қол жеткізу үшін тиісті метафоралар қолданылады.

Түйін сөздер: Орталық Азия, Тақырып ретінде мерзімді басылымдар, Гипотеза, Зерттеу дизайны

Дәйексөз үшін: Ривера Х. Дамушы елдердегі авторлық құқықтарды бұзулар. Медициналық гипотеза мен этиканың Орта Азиялық журналы.- 2020. - №1 (1). - Б. 69 - 74. https://doi.org/10.47316/cajmhe.2020.1.1.11

\section{Резюме}

\section{Злоупотребления в области авторства в развивающихся странах}

Несмотря на то, что в странах с низким и средним уровнем дохода (СНСД), а также в развитых странах задокументированы схожие научные злоупотребления в ходе проведения исследований, злоупотребления в области авторства и связанные с этим проблемы более распространены в первой группе стран. В этой статье рассматриваются вопросы, связанные с авторством в СНСД: споры об авторстве, чрезмерное соавторство и денежные стимулы, проблемы авторства в отношениях между учеником и наставником, модели авторства при сотрудничестве по типу Север-Юг. Университеты и официальные органы в СНСД должны контролировать целостность всего исследовательского процесса, предоставлять инструкции для корректного проведения исследований и определения авторства, создавать программы последипломного обучения, создавать образцовые примеры для подражания, назначать омбудсмена для консультирования и рассмотрения жалоб исследователей (особенно студентов и младших научных сотрудников). Наконец, должна быть сформирована основа, которая объединила бы описательные и нормативные элементы, а также использовала бы надлежащие фрормулировки для этически корректного определения авторства, актуального в международных условиях.

Ключевые слова: Центральная Азия, Периодика как тема, Гипотеза, Дизайн исследования Для цитирования: Ривера X. Злоупотребления в области авторства в развивающихся странах. Центральноазиатский журнал медицинских гипотез и этики. - 2020. - №1(1). - С. 6974. https://doi.org/10.47316/cajmhe.2020.1.1.11 